\title{
INFORMATIONAL SOCIETY AND OPTIMIZATION OF EDUCATION IN THE CURRENT CIRCUMSTANCES: RUSSIAN AND ARMENIAN EXPERIENCE
}

\author{
(c) Nina G. Keleberda, Arthur V. Atanesyan \\ Rostov Law Institute of the Ministry of Internal Affairs of the Russian Federation, \\ Rostov-on-Don, Russian Federation; \\ Yerevan State University, Yerevan, Armenia \\ science-almanac@mail.ru
}

The introduction of technology into education leads to a revision of the boundaries of knowledge: disciplines disappear, the "territories" of sciences are eroded, making room for (so to speak) "network research." The hypothesis is put forward that the optimization of education is both a condition and a consequence of an ideological shift. The content of the concept "optimization of education" in the context of the development of digital technologies in education is considered, defining "optimization" as a technique. The novelty of the research is presented by a comparative analysis of the development of the process of optimizing education in Russia and in Armenia. The relevance of this approach is due to the need to coordinate efforts to develop the information society both in the format of bilateral relations between Russia and Armenia, and within the Black Sea states. The authors rely on the analysis of the concepts of national developments, which fix the prospects and goals of the development of information technologies and the information society in Russia and Armenia. Having studied the strategic sectors and technological spheres of Armenia, it is concluded that Armenia, being a regional leader in the development of information technologies, supplies most of these developments to the USA and Canada, and a smaller part to Russia. The conclusion confirms the hypothesis that the introduction of new digital technologies in the educational process carries certain risks due, on the one hand, to the quality of educational services in the context of optimizing the educational process, and on the other, to a radical change in the consciousness and thinking of a modern person with using the same optimization.

Key words: Russia, Armenia, information society, optimization of education, digital science, digitalization, information technologies.

\section{[Н.Г. Келеберда, А.В. Атанесян Информационное общество и оптимизация образования в со- временных условиях: опыт России и Армении]}

Внедрение техники в образование приводит к пересмотру границ знания: дисциплины исчезают, размываются «территории» наук, освобождая место для (если можно так выразиться) «сетевых исследований». Выдвигается гипотеза о том, что оптимизация образования является одновременно и условием, и следствием мировоззренческого сдвига. Рассматриваются содержание концепта «оптимизация образования» в контексте развития цифровых технологий в образовании, определяя «оптимизацию» как технический прием. Новизну исследования представляет сравнительный анализ развития процесса оптимизации образования в России и в Армении. Актуальность такого подхода обусловлена необходимостью координации усилий по развитию информационного общества как в формате двухсторонних отношений России и Армении, так и в рамках государств Причерноморья. Авторы опираются на анализ концепций национальных развитий, в которых закрепляются перспективы и цели развития информационных технологий и информационного общества в России и Армении. Изучив стратегические секторы и технологические сферы Армении, делается вывод, что Армения, будучи региональным лидером по разработке информационных технологий, большую часть этих разработок поставляет в страны США и Канаду, и меньшую часть - в Россию. В заключении подтверждается гипотеза о том, что внедрение новых цифровых технологий в образовательный процесс несёт определенные риски, обусловленные, с одной стороны, качеством образовательных услуг в условиях оптимизации образовательного процесса, а с другой - радикальным изменением сознания и мышления современного человека с помощью все той же оптимизации.

Ключевые слова: Россия, Армения, информационное общество, цифровизация, оптимизация образования, информационные технологии. 
Nina G. Keleberda - Ph.D. in Philosophy, Associate Professor, Rostov Law Institute of the Ministry of Internal Affairs of the Russian Federation, Rostov-on-Don, Russian Federation.

Arthur V. Atanesyan - Ph.D. (Advanced Doctorate) in Politics, Professor, Yerevan State University, Yerevan, Armenia.

Келеберда Нина Григорьевна - кандидат фолософрских наук, доцент, Ростовский юридический институт Министерства внутренних дел Российской Федерации, г. Ростов-на-Дону, Российская Федерация.

Атанесян Артур Владимирович - доктор политических наук, профрессор, Ереванский государственный университет, г. Ереван, Армения.

Changes in the attitude of people, profound mass shifts change the face of economic, political and social life: there is a transformation of political and economic goals, religious norms and family values. Such changes, in turn, affect the rates of economic growth, the strategic attitudes of state power, as well as the prospects for public institutions.

The series of high-profile sensations over the past two or three years concerning plans to introduce "digital technologies" is not accidental, but systemic. Back in 2000, July 22, on the island of Okinawa, Japan, the presidents of the G8 countries signed the Okinawa Charter of the Global Information Society. This is a programmatic political document that determines the formation and development of a single global network informationcellular society of the 21st century, or otherwise "global network". The document explicitly states that "Information and communication technologies (IT) are one of the most important factors influencing the formation of society in the 21st century. Their revolutionary impact concerns the way of life of people, their education and work, as well as the interaction of government and civil society" [14].

On August 28, 2008, the Government of Armenia approved the «Concept for the Development of the Information Technology Sphere». The main goal of the concept approved by the government is to consolidate the prospects and goals of the development of information technologies and the information society in Armenia. The document also identifies the main challenges on this path and strategic approaches to overcome them, the main stages in the development of the field of information technology [13].

The President of the Russian Federation approved the federal target program "Strategy for the development of the information society in the Russian Federation for 2017 2030 " in 2017, in which the information society is defined as "a society in which information and the level of its use and availability radically affect the economic and sociocultural living conditions of citizens" [16]. And here it is indicated that the information society is a knowledge society in which "the predominant importance for the development of the citizen, the economy and the state are the receipt, preservation, production and dissemination of reliable information, taking into account the strategic national priorities of the Russian Federation" [16. p.4 I]. The acquisition of knowledge is equated with the production of information.

It should also be noted that the Russian Federation and the Republic of Armenia are coordinating efforts to develop the information society both in the format of bilateral relations and within the Commonwealth of Independent States [11].

In social philosophy, the concepts of "information society" and "knowledge society" appear in the works of Western sociologists: E. Toffler, D. Bell, M. Castells and others. Daniel Bell's classic work, The Coming Post-Industrial Society, dates from 1973 [2]. In modern Russian philosophy, attempts to investigate the philosophical premises of "numbers" are fragmentary. Basically, modern Russian researchers rely on foreign classics 
"numbers". Affected by the lack of specialists with fundamental knowledge and skills in conducting scientific research in the field of humanities and at the same time ITtechnologies.

It should be noted that today there are about 400 IT companies operating in Armenia, half of them are based on foreign capital. More than 10 thousand programmers and software development engineers are employed in the field. Let us add that more than half of these companies have been operating in Armenia since 2007. Armenia's IT sector is mainly export-oriented. Most of the products manufactured by Armenian specialists are sent to the USA, Canada and EU countries; unfortunately, fewer go to Russia [1].

Major government changes, various local and international initiatives, and close collaboration have contributed to the continuous growth of the country's ICT sector. The creation of the Ministry of High-Tech Industry in Armenia (previously the sector was regulated by the Ministry of Transport, Communications and Information Technologies) is clearly a step forward in terms of improving efforts and resources in the IT industry [19]. Sociologist Manuel Castells [5] notes that the specificity of the information society is the creation of a new type of information technology, for which information is both a "raw material" and a "product of production", considering this ratio to be the core characteristic of the information society.

However, not any knowledge is of value, but only "digitized" knowledge used in innovative technologies, which allows to obtain an immediate economic effect. It is the immediate economic effect that is the cause and driving force of the process of "optimization" in education. In modern pedagogical literature, we quite often come across different interpretations of the term "optimization of the learning process." To exclude a difference in interpretation, it is important to clarify its meaning, which is undoubtedly associated with the development of information technologies while simultaneously weakening the encyclopedic principle of constructing classical knowledge. Previously, the principle of encyclopedicity meant that each science finds its place in the general structure of knowledge.

Speaking about the logic of globalization, the famous American journalist T. Friedman writes in his book "Discworld" that the boundaries of states and societies, as well as knowledge, are blurred through the introduction of global information technologies of communication and management. As a result, not only differences are erased, but also features, including the advantages and achievements accumulated over the centuries, and the general level of education is averaged [20]. Accordingly, the introduction of technology into education leads to a revision of the boundaries of knowledge: disciplines disappear, the "territories" of sciences are eroded, making room for (if I may say so) "network research", which are not hierarchical in the classical sciences, but "flat »: Knowledge is considered to be established, therefore, faculties of higher educational institutions with the help of didactics reproduce teachers rather than scientists.

We find confirmation in the Federal Law on Education № 273 as amended in 2019, which provides a clear distinction between scientific and pedagogical workers of higher education: "pedagogical workers belong to the teaching staff" [12]. At the same time, scientists became researchers, since "network research" poses so many tasks that they can be solved only in parts, since no one has the whole knowledge. Hence the axiomatics of the language: the researcher creates a set of symbols and rules that he proposes to use as a language on the basis of a preliminary agreement, although the rules are very flexible and constantly change. That is, the rules within network research are constantly changing, creating an infinite number of models of systems, while gaining the power of persuasion, in other words, becoming evidence and gaining the approval of experts. These are purely technical techniques that obey the principle of optimization. 
Optimization is an increase in output, that is, information received, and a reduction in input, that is, energy expended. This technique is "good" only if it allows you to do better and / or spend less than the other. The best input / output ratio is efficiency. The criteria for assessing knowledge do not fluctuate in the plane "right / wrong", "true / false", but in the plane "effective / ineffective". N. Luhmann [8] believes that the laws of efficiency replace normativity: the one who owns more advanced technical means, he has at his disposal more knowledge and the ability to make decisions, that is, to be right. Therefore, technology is bought not to learn the truth, but to increase the productivity of knowledge.

Hence, the criterion of the effectiveness of teaching in a higher educational institution is expressed in the formation of competencies, the set of which is either needed by the system, or can be "sold" on the world labor market. Hence the requirement to form not ideals, but competencies necessary for a given profession. Therefore, the acquisition of new knowledge by students is associated with new techniques and new technologies, but in accordance with a single didactic model. In this context, elementary training in informatics should become an obligatory part of the teacher's professional training, especially since electronic "data banks" are becoming an analogue of the encyclopedic nature of knowledge.

In the context of the effectiveness of knowledge, it seems promising to form not so much professional competencies assessed by the criterion "right / wrong", but the socalled "operational competencies", that is, the ability to update the appropriate data from the "databank" to solve them into an effective strategy.

Obtaining information, even additional one, is not the goal of teaching a discipline, since the professor does not have comprehensive information of the last resort. The goal of teaching in the context of "digitalization" is the formation of the ability to organize incompatible data, as a result of which new data, or models, or techniques, or rules appear. Thus, inevitably, among the skills and abilities of students, it is necessary to form imagination and speed, which increase efficiency. Imagination is necessary as the ability to articulate isolated information fields, which requires, firstly, an interdisciplinary approach, and, secondly, the ability to generate new data, models, techniques, rules. The maximum "acceleration of imagination" becomes a condition for the effectiveness of teaching. This can be called "digitized knowledge", for the effective support of which it is necessary to change the existing traditional socio-cultural configurations, as well as to solve a number of technical problems to create new knowledge infrastructures based on information technologies.

Modern information technologies are part of the educational process in Armenia, and serve to include students in the system of modern communications, which are also directly related to their professional activities in the future [7]. Modern programs of advanced training and retraining of teachers of the Higher School, in particular "Direct-Academy" or the Arzamas branch of the Lower-City University named after N.I. Lobachevsky, e-learning technologies in teaching disciplines, including humanitarian ones, are a mandatory component. This is not only the use of cloud services, Learning service. apps, Google Sheets or the use of social networks and messengers as educational platforms, but also "gamification" of learning using various digital tools, for example, Winner, etc. Similarly, more than 15 years on the basis of the Faculty of Sociology of the Yerevan State University actively operates a platform for distance education, covering not only the internal, but also the regional audience [16]. The use of "network games" in the study of disciplines is designed to promote the development of imagination and speed in students in the search and processing of information.

However, play is an arbitrarily established system of values within one situation. Therefore, when the situation changes, the system of values established between the par- 
ticipants does not work and must change or disappear. If in the format of the "network game" serious questions concerning fundamental basic values are considered, then students develop a relativistic attitude towards these values, which is projected onto real vital values. Which, according to R. Inglhart [4], corresponds to the context of postmodernism. $\mathrm{R}$. Inglehart writes that the source of postmodern values is a sense of existential security: this is a shift in attitudes, when survival (vital values) can be taken for granted. Postmaterial values reflect a subjective sense of a person's economic and physical security, and not his level of well-being. Therefore, priorities are given to self-expression and quality of life, although economic and physical security is assessed positively. In addition, gaming technologies of education exclude the psychological need for absolute criteria.

The transformation of the world attitude can be viewed from the point of the concept of "human nature".

In an information society, the relationship between man and nature, including his nature, that is, man's self-understanding becomes technology-mediated. The relationship transformation scheme can be represented as follows:

\section{Relationship transformation scheme}
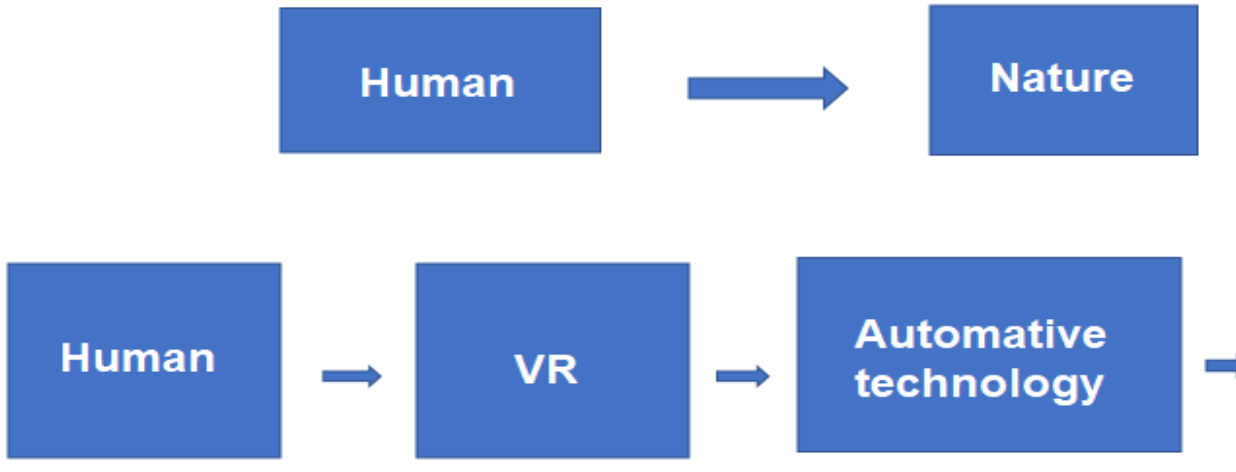

Nature

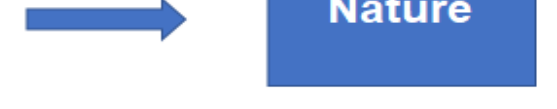

fig.1

The first diagram represents the traditional non-mediated relationship between a person and the outside world. In the second case, we see that these changes are multilayered. The nature of virtual reality, which in technical language is called "software product", in philosophy has not been sufficiently studied. It can be assumed that virtual reality is analogous to human thought. But the situation when a person creates virtual reality with his thoughts with the help of technologies is no longer relevant. Thus, it is obvious that digitalization is associated with certain risks, therefore, it should be subjected to serious philosophical analysis, the results of which should be taken into account when planning the educational process.

The formation of the values of the Homo Ludens (playing man) [17] in the learning process is the "advancement" of the shift in the world attitude. The consequence of the transformation of the traditional understanding of the relationship between nature and man was prophetically foreseen by R. Musil [10] in the novel "Man without properties". A person without properties does not have specific goals, does not have the discipline of thoughts and feelings, does not allow contemplation. His pleasure is momentary, his reading is rapidly changing, he has no time, he needs short communications that do not require effort for perception. Therefore, he avoids lofty words that have content. For him, word play is important, consisting in an unusual combination of words that attracts attention. Communica- 
tive competence is the ability to arrange words in a new way, to create unfamiliar names, vague statements. Communication comes down to technical skill. But in technical perfection, as K. Jaspers writes, "there is no core that would allow the less perfect to like and become essential" [18].

For a person without features, the need for self-expression and the need for communication become vital values. But a person-without-properties is not burdened with philosophical problems about good and evil, about the beautiful and ugly in the traditional sense. The expression of a person-without-properties is devoid of moral and aesthetic constants and is conditioned by momentary imagination. Expressive imagination, mediated by automated technology, is inherently alien to the aesthetic field, since the "signs" it creates have no aesthetic goals [6]. Such is the tragicomedy of the "game" of a person without properties, who continues to demand those very qualities whose very existence itself makes it impossible.

Meanwhile, "play" in the semantic meaning of the expressive behavior of a person in society as a value is enshrined in the European Convention of November 4, 1950, which, along with the right to life, states "the right to freely express one's opinion" [3]. Jim Murdoch [9] showed on the basis of the jurisprudence of the ECHR (European Court of Human Rights) that free expression of opinion can cause widespread deviance in society and an increase in the number of hate crimes [15].

The relativity and arbitrariness of game values lead to deep psychological uncertainty, which gives rise to a strong need for predictability. The logical consequence is the need for a criterion for assessing behavior that is independent of the situational-game subjectivity. As such a criterion is currently proposed "figure". Obviously, "riding the figure" means not only radical changes in the economy, but also a radical change in the consciousness and thinking of a modern person.

All of the above risks should be taken into account both in the development of the information society and in the plans for the introduction of the latest information technologies in the educational process. In conclusion, we note that, since the development of the information society is determined by the quality of education, the optimization of educational and methodological support of learning in the context of "digitalization" largely depends on the level of proficiency of the e-learning teacher.

\section{Лumepamypa}

1. Араратян Э. Армения: региональный лидер информационных технологий [Электронный источник] // Пресс-клуб СОДРУЖЕСТВО, 26.06.2016. URL: http://press-unity.com/stati/3674.html (дата обращения 13.07.2020).

2. Белл Д. Грядущее постиндустриальное общество: опыт социального прогнозирования / Даниел Белл; Пер. с англ. под ред. В. Л. Иноземцева. Москва: Academia, 2004 (ОАО Можайский полигр. комб.). 783 с.

3. Европейская конвенция от 4 ноября 1950 года «О защите прав человека и основных свобод» (с изм., внесенными протоколом от 13.05.2004. № 14) ст. 10. [Электронный источник] // URL: http://www.echr.ru/index.asp (дата обращения: 03.07.2020).

4. Инглхарт Р. Постмодерн: меняющиеся ценности и изменяющиеся общества // Полис. 1997. № 4. С. 6-32.

5. Кастельс М. Информационная эпоха: Экономика, общество и культура / Мануэль Кастельс; пер. с англ. под науч. ред. О.И. Шкаратана; Гос. ун-т. Высш. шк. экономики. Москва, 2000. 606 с. 
6. Келеберда Н.Г. Религия и искусство в постсекулярном ландшафте: вызовы или взаимодействие? // Южный Полюс 2017, т. 3, № 1. С. 108-114.

7. Киракосян М.Ж. Проблемы и способы интеграции информационных технологий в процесс обучения (опыт Армении) // Человек и образование. № 3 (24). 2010. С. 148-152.

8. Луман Н. Общество как социальная система. Пер. с нем./ А. Антоновский. М: Издательство "Логос". 2004. - 232 с.

9. Мёрдок Д. Защита права на свободу мысли, совести и религии в рамках Европейской конвенции о защите прав человека. Серия пособий Совета Европы. Воронеж: ООО Фирма «Элист», 2014 - 163 с.

10. Музиль P. Человек без свойств [Электронный источник] // URL: http://knijky.ru/books/chelovek-bez-svoystv?page=15 (дата обращения 30.04.2020).

11. Нейман А. России и Армении стоит плотнее сотрудничать в сфрере развития информационного общества [Электронный источник] // 06.06.2017 URL: https://ugra-news.ru/article/06062017/49863/ (дата обращения 13.07.2020)

12. Об образовании в Российской Федерации - Федер. закон N 273-Ф3 от 29 декабря 2012 г. с изменениями 2019. ст. 50. Научно-педагогические работники. [Электронный источник] // URL: http://base.garant.ru/70291362/ (дата обращения 30.04.2020).

13. Одобрена концепция развития сфреры информационных технологий. 28.08.2008 [Электронный источник] // https://www.panorama.am/ru/news/2008/08/28/it/1305157 (дата обращения 13.07.2020)

14. Окинавская хартия глобального информационного общества" от 21 июля 2000 года. [Электронный источник] // http://base.garant.ru/2560931/ (дата обращения 13.07.2020).

15. Преступления на почве ненависти: суть проблемы: Памятка для государственных органов Украины. Бюро ОБСЕ по демократическим институтам и правам человека, Варшава: Poligrafus Jacek Adamiak. БДИПЧ ОБСЕ, 2015. 24 c.

16. Указ Президента РФ от 9 мая 2017 г. № 203 “О Стратегии развития информационного общества в Российской Федерации на 2017 - 2030 годы” [Электронный источник]. URL: https://www.garant.ru/products/ipo/prime/doc/71570570/ (дата сохранения: 18.01.2020).

17. Хёйзинга Й. Homo Ludens; Статьи по истории культуры. (Пер., сост. и вступ. ст. Д.В. Сильвестрова). М.: Прогресс - Традиция, 1997. 416 с.

18. Ясперс, Карл. Д Духовная ситуация времени / Карл Ясперс; [пер. с нем. М. И. Левиной]. Москва: АСТ, 2013. 285 с.

19. Erlanger A. IT в Армении: стратегические секторы и технологические сореры страны. [Электронный источник]. 7.10.2019. URL: https://habr.com/ru/post/470511/ (дата обращения 10.07.2020).

20. Friedman T.L. (2007). The world is flat: a brief history of the twenty-first century. 1st Picador ed., Further updated and expanded, [Pbk. ed.]. New York: Picador/Farrar, Straus and Giroux.

\section{References}

1. Araratyan E. Armeniya: regionalnyy lider informatsionnykh tekhnologiy. [Armenia: Regional Leader of Information Technologies]. SODRUZHESTVO Press Club, 
26.06.2016. Available at: http://press-unity.com/stati/3674.html, free (accessed 13.07.2020) (In Russian).

2. Bell D. Gryadushcheye postindustrialnoye obshchestvo: opyt sotsialnogo prognoziro-vaniya. [The coming post-industrial society: the experience of social forecasting]. Daniel Bell; Per. from English. ed. V.L. Inozemtseva. Moscow: Academia, 2004 (OJSC Mozhaisk polygraph. Comb.). 783 p. (In Russian).

3. Yevropeyskaya konventsiya. ot 4 noyabrya 1950 goda «O zashchite prav cheloveka i os-novnykh svobod» (s izm., vnesennymi protokolom ot 13.05.2004. № 14) st. 10. [European convention of November 4, 1950 " European Convention on Human Rights" as amended by Protocols Nos. 11 and 14]. Available at: http://www.echr.ru/index.asp, free (accessed 03.07.2020) (In Russian).

4. Inglkhart R. Postmodern: menyayushchiyesya tsennosti i izmenyayushchiyesya obshchestva. [Postmodernity: changing values and changing societies]. Polis. 1997. No. 4. pp. 6-32 (In Russian).

5. Kastels M. Informatsionnaya epokha: Ekonomika, obshchestvo i kultura. [Information Age: Economy, Society and Culture. Translation from English]. Higher School of Economics. Moscow, 2000. 606 p. (In Russian).

6. Keleberda N.G. Religiya i iskusstvo v postsekulyarnom landshafte: vyzovy ili vzaimodeystviye? [Religion and Art in the Post-Secular Landscape: Challenges or Interaction?]. Yuzhnyy Polyus, 2017. vol. 3, No. 1. pp. 108-114 (In Russian).

7. Kirakosyan M.Zh. Problemy i sposoby integratsii informatsionnykh tekhnologiy $v$ protsess obucheniya (opyt Armenii). Chelovek i obrazovaniye [Problems and methods of integrating information technologies into the learning process (the experience of Armenia). Man and education]. № 3 (24). 2010. pp 148-152 (In Russian).

8. Luman N. Obshchestvo kak sotsial'naya sistema. Perevod s nemetskogo [Society as a social system. Translated from German]. A. Antonovskiy. M: Izdatelstvo "Logos". 2004. 232 p. (In Russian).

9. Mordok D. Zashchita prava na svobodu mysli, sovesti i religii v ramkakh Yevropeyskoy konventsii o zashchite prav cheloveka. Seriya posobiy Soveta Yevropy [Protection of the right to freedom of thought, conscience and religion in the framework of the European Convention for the Protection of Human Rights. Council of Europe manual series]. Voronezh: OOO Firma «Elist», 2014.163 p. (In Russian).

10. Muzil R. Chelovek bez svoystv [Man without properties]. Available at: http://knijky.ru/books/chelovek-bez-svoystv?page=15, free (accessed 30.04.2020) (In Russian).

11. Neyman A. Rossii i Armenii stoit plotneye sotrudnichat' v sfere razvitiya informatsionnogo obshchestva [Russia and Armenia should cooperate more closely in the development of the information society]. Available at: https://ugranews.ru/article/06062017/49863/, free (accessed 13.07.2020) (In Russian).

12. Ob obrazovanii v Rossiyskoy Federatsii - Feder. zakon N 273-FZ ot 29 dekab-rya 2012 g. s izmeneniyami 2019. st. 50. Nauchno-pedagogicheskiye rabotniki [About education in the Russian Federation - Feder. Law No. 273-Federal Law dated December 29, 2012 as amended in 2019. 50. Scientific and pedagogical workers]. 
Available at: http://base.garant.ru/70291362/, free (accessed 30.04.2020) (In Russian).

13. Odobrena kontseptsiya razvitiya sfery informatsionnykh tekhnologiy. 28.08.2008. [The concept of development of the information technology sphere was approved]. Available at: https://www.panorama.am/ru/news/2008/08/28/it/1305157, free (accessed 13.07.2020) (In Russian).

14. Okinavskaya khartiya globalnogo informatsionnogo obshchestva" ot 21 iyulya 2000 goda [Okinawa Charter of the Global Information Society dated July 21, 2000]. Available at: http://base.garant.ru/2560931/, free (accessed free 13.07.2020) (In Russian).

15. Prestupleniya na pochve nenavisti: sut' problemy: Pamyatka dlya gosudarstvennykh organov Ukrainy. Byuro OBSE po demokraticheskim institutam i pravam cheloveka [Hate Crimes: The Heart of the Problem: A Memo for State Bodies of Ukraine. OSCE Office for Democratic Institutions and Human Rights]. Varshava: Poligrafus Jacek Adamiak. BDIPCH OBSE, 2015. 24 p. (In Russian).

16. Ukaz Prezidenta RF ot 9 maya 2017 g. № 203 "O Strategii razvitiya informatsionnogo obshchestva v Rossiyskoy Federatsii na 2017-2030 gody" [Decree of the President of the Russian Federation of May 9, 2017 No. 203 "On the Strategy for the Development of the Information Society in the Russian Federation for 20172030"]. Available at: https://www.garant.ru/products/ipo/prime/doc/71570570, free (accessed: 18.01.2020) (In Russian).

17. Khoyzinga Y. Homo Ludens; Stati po istorii kultury [Homo Ludens; Articles on the history of culture] Moscow: Progress-Tradition, 1997. 416 p. (In Russian).

18. Jaspers K. Dukhovnaya situatsiya vremeni [Spiritual situation of time] / Karl Yaspers;Moskva: AST, 2013. 285 p. (In Russian).

19. Erlanger A. IT v Armenii: strategicheskiye sektory i tekhnologicheskiye sfery strany [IT in Armenia: strategic sectors and technological spheres of the country]. Available at: https://habr.com/ru/post/470511/, free (accessed: 10.07.2020) (In Russian).

20. Friedman T.L. (2007). The world is flat: a brief history of the twenty-first century. 1st Picador ed., Further updated and expanded, [Pbk. ed.]. New York: Picador/Farrar, Straus and Giroux. 